\title{
Effect of temperature, food availability, and estradiol injection on gametogenesis and gender in the pearl oyster Pinctada margaritifera
}

\author{
Teaniniuraitemoana Vaihiti ${ }^{1}$, Leprêtre Maxime ${ }^{1}$, Levy Peva ${ }^{1}$, Vanaa Vincent ${ }^{1}$, Parrad Sophie ${ }^{1}$, \\ Gaertner-Mazouni Nabila ${ }^{2}$, Gueguen Yannick ${ }^{3}$, Huvet Arnaud ${ }^{4}$, Le Moullac Gilles ${ }^{1,}$
}

\footnotetext{
${ }^{1}$ Ifremer; UMR 241 Ecosystèmes Insulaires Océaniens (EIO); Labex CORAIL; Centre du Pacifique; Taravao Tahiti French Polynesia

${ }^{2}$ Université de la Polynésie Française, UMR 241 Ecosystèmes Insulaires Océaniens (EIO), Labex CORAIL; Faa'a Tahiti French Polynesia

${ }^{3}$ Ifremer; UMR 5244 Interactions Hôtes-Pathogènes-Environnement (IHPE); Université de Montpellier; Montpellier Cedex 5 France

${ }^{4}$ Ifremer; UMR 6539 Laboratoire des sciences de I'Environnement Marin (LEMAR); ZI de la Pointe du Diable; Plouzané France
}

*Corresponding author : Gilles Le Moullac, email address : Gilles.Le.Moullac@ifremer.fr

\begin{abstract}
:
The black-lip pearl oyster Pinctada margaritifera is a protandrous hermaphrodite species. Its economic value has led to the development of controlled hatchery reproduction techniques, although many aspects remain to be optimized. In order to understand reproductive mechanisms and their controlling factors, two independent experiments were designed to test hypotheses of gametogenesis and sex ratio control by environmental and hormonal factors. In one, pearl oysters were exposed under controlled conditions at different combinations of temperature $\left(24\right.$ and $\left.28^{\circ} \mathrm{C}\right)$ and food level $(10,000$ and 40,000 cells $\mathrm{mL}^{-1}$ ); whereas in the other, pearl oysters were conditioned under natural conditions into the lagoon and subjected to successive $17 \beta$-estradiol injections (100 $\mu \mathrm{g}$ per injection). Gametogenesis and sex ratio were assessed by histology for each treatment. In parallel, mRNA expressions of nine marker genes of the sexual pathway (pmarg-foxl2, pmarg-c43476, pmarg-c45042, pmarg-c19309, pmargc54338, pmarg-vit6, pmarg-zglp1, pmarg-dmrt, and pmarg-fem1-like) were investigated. Maximum maturation was observed in the treatment combining the highest temperature $\left(28^{\circ} \mathrm{C}\right)$ and the highest microalgae concentration $\left(40,000\right.$ cells $\left.\mathrm{mL}^{-1}\right)$, where the female sex tended to be maintained. Injection of $17 \beta$-estradiol induced a significant increase of undetermined stage proportion 2 weeks after the final injection. These results suggest that gametogenesis and gender in adult pearl oysters can be controlled by environmental factors and estrogens. While there were no significant effects on relative gene expression, the 3-gene-pair expression ratio model of the sexual pathway of $P$. margaritifera, suggest a probable dominance of genetic sex determinism without excluding a mixed sex determination mode (genetic + environmental)
\end{abstract}




\section{Introduction}

The black pearl industry, which is the second most important economic resource forFrench Polynesiaafter tourism, is based on the exploitation of the black-lip pearl oyster Pinctadamargaritifera (L.). Breeding of selected donor oyster linesproviding highperformance graft tissue is a way to improve the production of quality pearls (Tayalé et al., 2012; Ky et al., 2013, 2014). Such genetic selection is based oncontrolledpearl oyster reproduction in laboratory, which requires an understanding of the physiological mechanisms involved and the factors controlling them(Gueguen et al., 2013).The artificial reproduction of the pearl oyster $P$. margaritiferaimpliesbeing able to control gametogenesis and the synchronization of maturity stagesof the breeders, butmostly importantly requires the management of sex ratio for broodstock husbandry, whichappears to be the mainlimitation. Indeed, reproduction of pearl oyster under controlled conditions mainly depends on the availability of females, which unfortunately are not abundant amongyoung farmed batches of this species due to itsprotandrous hermaphroditism (Tranter, '58). This particular reproductive strategy pose a problem of generation time for the renewal of oyster lines in hatcheries because it takes 4-5 years for a significant number of females to produce offspring (Chávez-Villalba et al., 2011).

In the animal kingdom, sex determination can be genetic (GSD); environmental (ESD); or the result of an interaction of both these factors (Valenzuela et al., 2003; Wedekind and Stelkens, 2010). The main factors involved in ESD mechanisms are temperature, food availability and population density (Pradeep et al., 2012). In marine bivalves, only a few studies have covered the influence of these latter parameters on sex ratio. Stenyakina et al.(2010) showed a male-biased sex ratio in fasting mussel $M$. charruana. In Pacific oyster Crassostreagigas, an alternative and irregular protandrous hermaphrodite, a male-biased sex ratio was obtained in adults by conditioning at low temperature $\left(8{ }^{\circ} \mathrm{C}\right)$ (Fabioux et al., 2005)whereas in spat of the same species it was obtained by conditioning at high temperature $\left(25^{\circ} \mathrm{C}\right)$ (Santerre et al., 2013).

The pearl oyster is a suspension feeder particularly abundant in the Polynesian archipelagos where annual temperatures range from 22 to $31^{\circ} \mathrm{C}$ (Zanini and Salvat, 2000; Fournier et al., 2012; Le Moullac et al., 2012). P.margaritifera reaches sexual maturity at the end of its first year. Its production of gametes is continuous, asynchronous, and linked to the pearloyster size (Pouvreau et al., 2000). Most studies show that the reproduction cycle in bivalves is generally influenced by environmental factors (Sastry, '79; Bayne and Newell, '83; Gervis and Sims, '92). In temperate areas,Fabioux et al.(2005)showed that the gametogenic cycle of $C$.gigas depends on temperature andfood availability. In tropical area such as French Polynesia,however, there is no clear seasonal cycle because there is little temperature variations. Pearl oysters are reproductively active almost all year round (Pouvreau et al., 2000; Le Moullac et al., 2012), withabundant trophic resources promoting gametogenesis and spawning(Fournier et al., 2012). A recent study in P.margaritifera confirmed that gametogenesis is modulated by food level:under-feeding decreases or stops germinal activity preventing any resumption of gametogenesis (Le Moullac et al., 2013). However, a betterunderstanding of the influence of environmental factors on gametogenesis remains essential for controlling this crucial step in the rearing cycle.

Although some debates occur in the scientific community (Scott, 2012, 2013), fluctuations in levels of sex steroidshave been found to be correlated with the sexual maturation cycle in a number of bivalves, thus suggesting that sex steroids may play important stimulatory roles in their reproductive regulation (Matsumoto et al., '97; Osada et al., 2004; Gauthier-Clerc et al., 2006; Ketata et al., 2007).This hypothesis is supported byVaraksina and Varaksin('91) and Varaksina et al. ('92) whoreported that injections of estradiol, progesterone and testosterone stimulated both oogenesis and spermatogenesis in adult Japanese scallop 
Mizuhopectenyessoensis. In the clamMulinialateralis, administration of methyltestosterone accelerated sex maturation and resulted in an increase in spawning frequency (Moss, '89), while estradiol injections stimulated vitellogenesis in the oyster C. gigas(Li et al., '98; Osada et al., 2003). There is also evidence indicating that the gender of bivalves can be affected by sex steroids.Moss, ('89), showed that methyltestosterone fed to spawned clam $M$. lateralisincreased the male/female ratio from 0.8 to 1.6. Mori et al.('69) showed that injection of estradiol into the oyster $C$. gigas at early stages of seasonal maturation induced sex reversal from male to female. In the pearl oyster $P$. margaritifera, no studies have yet been published on the possible effects of sex steroids on gametogenesis or gender determination.

The genetic and/or environmental process that establishes the gender of an organism (Penman and Piferrer, 2008), leads to specific molecular cascades transforming an undifferentiated gonad into a testis or an ovary (Piferrer and Guiguen, 2008). Recently, a gonad transcriptome analysis of P.margaritifera, using Illumina-based RNAseq, made it possibleto propose a new model of the reproduction of $P$. margaritifera based on a dual histo-molecular approach(Teaniniuraitemoana et al., 2015); this revealed thatthe regression phase of the gonad could open the time window for adult sex-determination. In addition, after examining expression of nine identified marker genes of the sexual pathway, a model was formed based on the expression ratios of 3 gene pairs. This model makes it possible to predict sexual pathway in this hermaphrodite species. This 3-genes-pair ratio sexual pathway signature concerns the ratiospmarg-c43476/pmarg-fem1-like, pmarg-fox/2/pmarg-c54338 and pmarg-foxl2/pmarg-fem1-like and strongly suggeststhe involvement ofpmarg-foxl2 and pmarg-fem1-like in sex determination and differentiation in $P$. margaritifera(Teaniniuraitemoana et al., 2015).

In this context, the main objective of the present study was to examine, using two separate experiments,(1) the effect of environmental combinationsof temperature (24 and $28{ }^{\circ} \mathrm{C}$ ) and trophic level $\left(10,000\right.$ and 40,000 microalgae cells $\left.\mathrm{mL}^{-1}\right)$ and (2) the effect of injected $17 \beta$ estradiol $(100 \mu \mathrm{g})$ on gender, especially sex ratio, gametogenesis and mRNA level of nine marker genes of the sexual pathway.

\section{Materials and Methods}

\subsection{Biological material}

The effect of environmental factors (temperature and trophic level) has been tested on 360three-years-old male and female adult pearl oysterswith an average size of $118 \mathrm{~mm} \pm$ 8.67. These pearl oysters were transportedfrom Takaroa (Tuamotu Archipelago, French Polynesia) to Vairao lagoon (Tahiti, French Polynesia) where they were acclimated for 3.5 months.

The effect of $17 \beta$-estradiol injection was tested on 260 two and a half-years-old male pearl oysters with an average size of $65 \mathrm{~mm} \pm 8.13$. These pearl oysterswere issued from a multifamilial cross, according to $\mathrm{Ky}$ et al.(2013), in the Ifremer hatchery by crossbreedingbroodstock oysters (4 males and 6 females)originated from the Apataki atoll (Tuamotu Archipelago, French Polynesia) in June 2011, and were reared in the Vairao lagoon.

\subsection{Initial biopsy and standardization by gonad regression}

Before the start (d0) of the two experiments (environmental: Exp1, February to April 2013; and hormonal:Exp2, January to March 2014), all pearl oysters $(n=360$ for Exp1 and $n=260$ for Exp2) were labeled individually and sexed by biopsy. They were then placed in the 
lagoon for a minimum of 2 weeksfor recovery. The biopsy was performed using a needle mounted on a piston syringe inserted in the gonadic part of the visceral mass to collect the gametes. Sex was determined by observation undera binoculardissecting microscope.

After the recovery period in the lagoon, pearl oysters were subjected toa period of underfeeding to stop the production ofgonial cells(Le Moullac et al., 2013)and synchronize gametogenesis. For Exp1, oysters were placed randomly in 8tanks $(250 \mathrm{~L})$ and then fed for 7 dayson 4,400 cells $\mathrm{mL}^{-1}$ microalgae (1/3 Chaetocerosgacilis and $2 / 3$ Isochrysisgalbana) at a temperature of $28{ }^{\circ} \mathrm{C}$. For Exp 2, oysterswere placed randomly in 26 tanks(30L) and maintained for ten days with continuously renewed sea water at $28{ }^{\circ} \mathrm{C}$ and a meanchlorophyll-a concentrationof $0.015 \mu \mathrm{L} \mathrm{L}^{-1}$. This phase ended by the sampling of 40 and 20 individuals in Exp1 and Exp2, respectively, to define the initial state ingametogenesis of population in eachexperiment before treatments.

\subsection{Pearl oyster conditioningaccording to temperature and trophic level (Exp1)}

Pearl oysters were reared attwo trophic levels $\left(10,000\right.$ cells $\mathrm{mL}^{-1}$ and 40,000 cells $\left.\mathrm{mL}^{-1}\right)$ and two temperatures $\left(24^{\circ} \mathrm{C}\right.$ to $\left.28{ }^{\circ} \mathrm{C}\right)$ for 8 weeks. Four experimental treatments were realized in the laboratory in duplicate $\left(24{ }^{\circ} \mathrm{C}-10,000\right.$ cells $\mathrm{mL}^{-1}, 24{ }^{\circ} \mathrm{C}-40,000$ cells mL $\mathrm{m}^{-1}, 28{ }^{\circ} \mathrm{C}-10,000$ cells $\mathrm{mL}^{-1}, 28{ }^{\circ} \mathrm{C}-40,000$ cells $\left.\mathrm{mL}^{-1}\right)$. Oysters $(\mathrm{n}=320)$ were distributed between 8 experimental tanks $(250 \mathrm{~L})$, with32 males and 8 females per tank. Seawater renewal $(100 \mathrm{~L}$ $\mathrm{h}^{-1}$ ) was maintained constant. Homogenization of the environment in the tanks wasachieved by "air-lifts", and photoperiod was maintained at 12:12. The tankswere cleaned once a week. Pearl oysters were fed with a mixed diet composed of 2:1 (v:v) of Isochrysisgalbana(TIso)and Chaetocerosgraciliscells, supplied continuously withBlackstone dosing pumps. Cooled sea water was produced using a plate heat exchanger stocked with cold fresh water, and warmed sea water was produced using a 2,500-watt electric heater. Each rearing tank wassampled automatically every 3 minfor fluorescence and temperature measurements. The fluorometer(???) wasfirst calibrated foralgal concentration (cells $\mathrm{mL}^{-1}$ ) and the temperature probe was calibrated using a reference electronic thermometer(???).After 30 days (d30), 16 males and 4 females were randomly sampled from each tank. The 160 remaining pearl oysters were sacrificed at the end of the experimentafter 60 days(d60) to assess the final state.

\subsection{Pearl oyster conditioning using estradiol injection (Exp2)}

$17 \beta$-estradiol $\left(E_{2}\right)$ was purchased from Sigma-Aldrich (Stenheim, Germany). $E_{2}$ was dissolved in $100 \%$ ethanol, which was then diluted 1:100 with 1- $\mu \mathrm{m}$ filteredsterilized seawaterto give a $0.5 \mu \mathrm{g} \mathrm{LL}^{-1}$ stock solution. From this solution, $200 \mu \mathrm{L}$ were injected directly into the gonad of each animal $(n=120)$. The remaining pearl oyster $(n=120)$, were injected with $200 \mu \mathrm{L}$ of a 1:100 mixture of ethanol and sterilized seawater toserve as a control. Three successive injections were performedonce a week at the beginning (day $0, d 0$ ), at day 7 (d7) and at day 14 (d14) of the experiment. To minimize stress caused by gonad injections, oysters were anesthetized using $\mathrm{MgCl}_{2}$ following the protocol provided bySuquet et al.(2009). After each injection, the pearl oysters were putback in the lagoon, where they were hung on ropes ingroups of 20 on a submerged long-line at $7 \mathrm{~m}$ depth.Two weeks after the last injection (d28), the first half of the pearl oysters was collected. The second half was sacrificed at the end of the experiment, 6 weeks after the final injection (d56).

\subsection{Histology}

For each oyster, gonad tissue was sampled for histological examination using methods described by Fournier et al. (2012).After dissection, each visceral masse was fixed in formalin solution $10 \%$ diluted in seawater for $48 \mathrm{~h}$ before being transferred to $70 \%$ ethanol for $48 \mathrm{~h}$ for preservation. Then, the visceral masses were cut along thesagittal plane with a 
microtome blade and were dehydrated through a graded ethanol series, embedded in paraffin, sectioned at 3-4 $\mu \mathrm{m}$ on a rotary microtome, stained with Giemsa dye and, finally, mounted on microscope slides.Gonad development stage and sex were then determined under a light microscope(???) and thus samples were classified according to theten different categories of gonadic tissues described previously in Teaniniuraitemoana et al. (2014):male and female at "Early" stage (the gonad is in early gametogenesis), "Intermediate" stage (the gonad is developing), at "Mature" stage (the oyster is ready to spawn), "Regressed" stage (the gonad has stopped generating gametes); "Inversion" (the gonad presents male and female gametes together)and "Undetermined" (the gonad contains no gametes at all).

\subsection{Real time PCR}

For each oyster, a piece of gonad tissue was sampled, putin RNAlater ${ }^{\mathrm{TM}}$ (Qiagen) (50 $\mathrm{mg} / \mathrm{mL}$ ) and then stored at $-80^{\circ} \mathrm{C}$ for subsequent total RNA extraction.

Total RNAwas extracted using TRIzol ${ }^{\circledR}$ Reagent (Invitrogen) and treated with DNAse I using a DNA-free ${ }^{\mathrm{TM}}$ Kit (Ambion) following manufacturer's instructions. RNA concentrations were measured using an ND-100 spectrophotometer (Nanodrop Technologies) at $260 \mathrm{~nm}$, using the conversion factor $1 \mathrm{OD}=40 \mu \mathrm{g} / \mathrm{mL}$ RNA.For each sample, $0.5 \mu \mathrm{g}$ of total RNA were reverse-transcribed using a Transcriptor First Strand cDNA Kit (Roche) and amplified by real time PCR on a Stratagene MX3000P. The amplification reaction contained $12.5 \mu \mathrm{L} 2 \mathrm{X}$ SYBR green qPCRMaster Mix (Stratagene), $10 \mu \mathrm{LcDNA}$ template, and $2.5 \mu \mathrm{L}$ ofeach primer $(4 \mu \mathrm{M})$ in a final volume of $25 \mu \mathrm{L}$. Each run included a positive cDNA control and a blank control (water) for each primer pair. Relativegene expression was calculated using two reference genes, ef1a and gapdh1, using the $2^{-\Delta C t}$ method (Livak and Schmittgen, 2001), as follows:

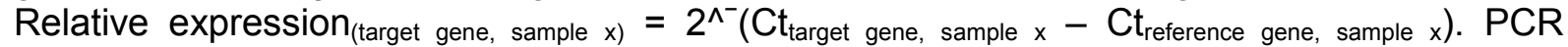
efficiency $(E)$ was estimated for each primer pair by determining the slopes of standard curves obtained from serial dilution analysis of the cDNA control to ensure that $E$ ranged from 90 to $110 \%$. The 9 primerpairs used for amplificationand described inTeaniniuraitemoana et al.(2015) are listed in Table 1.

\subsection{Molecular sexual pathway determination}

To determine the molecular sexual pathway of oysters, we used the model proposed byTeaniniuraitemoana et al.(2015) based on the expression ratios of four genes: pmargc43476/pmarg-fem1-like, pmarg-foxl2/pmarg-c54338 and pmarg-foxl2/pmarg-fem1-like. According to this model, oysters aremolecularly on thefemale pathway when they combine a pmarg-c43476/pmarg-fem1-like gene ratio $\geq 0.02225$ and a pmarg-foxl2/pmarg-c54338 gene ratio $\geq 12.25$; or a pmarg-c43476/pmarg-fem1-like gene ratio $\geq 0.02225$, a pmargfox/2/pmarg-c54338 gene ratio $<12.25$ and a pmarg-fox/2/pmarg-fem1-like gene ratio $\geq$ 0.1003 . Oystersare on the male pathway when they present a pmarg-c43476/pmarg-fem1like gene ratio $<0.02225$ or a combining pmarg-c43476/pmarg-fem1-like gene ratio $\geq$ 0.02225 , a pmarg-foxl2/pmarg-c54338 gene ratio < 12.25 and a pmarg-foxl2/pmarg-fem1-like gene ratio $<0.1003$.

\subsection{Statistical analysis}

Gametogenesis, sex ratio and sexual pathway were analyzed using Fischer's exact testin XLStat software. The mean of relative gene expressions were compared using the nonparametric Kruskall-Wallis test, and pairwise multiple comparisons were carried out according to the procedure of Wilcoxon using Bonferroni correction inR software ( $R$ Development Core Team, 2011). All these statistical analyses were conducted with the threshold of significance $\alpha=0.05$. 


\section{Results}

\subsection{Effects of temperature and trophic levelon gametogenesis and sex ratio}

Significant differences in the proportion of reproductive stages were revealed between the different treatments(Fisher's exact test;pvalue<0.05)in the two experiments (Fig. 1 and 2). At d0 of experimentation(initial state), there was a significantly higher proportion of regressed gonads, than that expected, with $100 \%$ and $80 \%$ in Exp1 and Exp2, respectively, probably caused by the initial under-feeding.

In the experiment testing environmental factors(Exp1, Fig. 1), after 60 days of conditioning, a significantly lower proportion(5\%) of mature gonadswas obtainedthan expected for pearl oysters conditioned at $24^{\circ} \mathrm{C}$ and 10,000 cells mL ${ }^{-1}$. For pearl oysters conditioned at $28{ }^{\circ} \mathrm{C}$ and 40,000 cells $\mathrm{mL}^{-1}$, a significantly higher proportion(65.7\%) of mature gonads was obtainedthan expected. In this latter treatment, a higher proportion of mature pearl oysterthan the expected distribution was also found after only 30 days of conditioning. Regressed gonads wereobserved in all temperature and trophic level combinations. Significantly higher proportions of regressed gonads were found in the treatmentcombining $24{ }^{\circ} \mathrm{C}$ and 10,000 cells $\mathrm{mL}^{-1}$ after both 30 and 60 days of conditioning. Pearl oysters in the regressed stage were also found in the treatment $28^{\circ} \mathrm{C}-40,000$ cells $\mathrm{mL}^{-1}$, but in significantly lower numbers than the expected distribution.

In addition, Fisher's exact test revealed significant differences in the proportion of females and animals in inversion(pvalue $<0.001$; Table 2). Conversely, the proportion of males did not change significantly. At d30, changes in the sex ratio were found only at low trophic level. In the $28{ }^{\circ} \mathrm{C}-10,000$ cells $\mathrm{mL}^{-1}$ treatment,three individuals became sexually undifferentiated, plus one female animaldied. At d60significant effects of environmental factors on the sex ratio were observed. At low trophic level and $28{ }^{\circ} \mathrm{C}$, a significant proportion of females $(50 \%)$ wasundergoing inversion to become male. In pearl oysters fed with a concentration of 40,000 cells $\mathrm{mL}^{-1}$, a significantlysmaller proportion of inversion was observed. At $24{ }^{\circ} \mathrm{C}$, two "female to male" inversions were observed whereas only one was seen at $28^{\circ} \mathrm{C}$.

\subsection{Effects of estradiol injection on sex ratio and gametogenesis}

In the hormonal experiment (Exp2, Fig.2), after 28 days, there were significantly higher proportions of regressed and undifferentiated gonads for pearl oysters injected with $17 \beta$ estradiol. These two stages were not found at all after 56 days in this treatment, where the mature stage then appeared significantly dominant $(51 \%)$ as in the control treatment $(60 \%)$. Some pearl oysters in regression were also found in the control group at the end of the experiment $(2 \%)$ but in significantly lower proportionsthan in the expected distribution.

The effect of $17 \beta$-estradiol injection was only tested inmalesin order to evaluatewhether induction of male to female sex-reversal was possible in $P$. margaritifera. Fisher's exact test (pvalue< 0.05) revealed significant differences in the proportion of male pearl oysterscompared with the expected distribution (Table 2). Indeed,for pearl oysters injected with $17 \beta$-estradiol and sampled at d28, there was a significant lower proportion $(82 \%)$ of males, whereas the proportion of undetermined individualsappeared significantly higher $(18 \%)$ than expected.

\subsection{Gene expression analysis reveals male pearl oysters at the onset of female differentiation}

Gene expression analysis of nine candidate marker genes (pmarg-foxl2, pmarg-c43476, pmarg-c45042, pmarg-c19309, pmarg-c54338, pmarg-vit6, pmarg-zglp1, pmarg-dmrt and 
pmarg-fem1-like)wasperformed on regressing maleand undeterminedsamples after 60 days of conditioning in Exp1 andafter 28 days in Exp2. Statistical testscarried out on mRNA levels did not show significant effects of environmental factors (Kruskal-Wallis) or 17ßestradiolinjection (Wilcoxon) on gene expression.

However, the use of the 3-gene-pair expression ratio model of the sexual pathway of $P$. margaritifera, proposed inTeaniniuraitemoana et al.(2015), on the present gene expression dataset revealedthat nine male pearl oysters exhibiteda female sexual molecular pathway (i.e. combining a pmarg-c43476/pmarg-fem1-like gene ratio $\geq 0.02225$ and a pmargfoxl2/pmarg-c54338gene ratio $\geq 12.25$; or combining a pmarg-c43476/pmarg-fem1-like gene ratio $\geq 0.02225$, a pmarg-fox/2/pmarg-c54338 gene ratio $<12.25$ and a pmarg-foxl2/pmargfem1-like gene ratio $\geq 0.1003$ ) (Table 3). One of these specimens was found in the treatment $28{ }^{\circ} \mathrm{C}-10,000$ cells $\mathrm{mL}^{-1}$ and another in $28{ }^{\circ} \mathrm{C}-40,000$ cells $\mathrm{mL}^{-1}$ and three were found in the treatment $24{ }^{\circ} \mathrm{C}-10,000$ cells $\mathrm{mL}^{-1}$ in Exp1. In Exp2, we found two individuals among the oysters injected with $17 \beta$-estradiol and two others in the control condition. Regarding their proportions, theFisher's exact test revealed significant differences in Exp1 but not in Exp2. Indeed,the proportion of oysters on the female and male pathways was significantly lower in treatments $24{ }^{\circ} \mathrm{C}-40,000$ cells $\mathrm{mL}^{-1}$ and $28{ }^{\circ} \mathrm{C}-40,000$ cells $\mathrm{mL}^{-1}$, respectively, than the expected proportions ( $p$ value $<0.05$; Fisher's exact test).

Comparing gene expression between individuals determined molecularly to be on female and male sexual pathways;Wilcoxon test revealed significant differences forpmarg-foxl2 and pmarg-fem1-like mRNA levels but not for the seven other genes tested (Fig. 3). Indeed, the mRNA level of pmarg-foxl2 appeared significantly higher (4.6E-05 $\pm 9.7 \mathrm{E}-05$; pvalue< 0.05$)$ in oysterson the female sexual pathway than in those on the male sexual pathway, whereas pmarg-fem1-like appeared significantly lower (1E-03 $\pm 4.4 \mathrm{E}-03$; pvalue< 0.01).

\section{Discussion}

In this study, we report the effect of different combination of temperature, food quantity and $17 \beta$-estradiolon gender determination and dynamics of gametogenesis in adult $P$. margaritifera. For this purpose, we conducted two separated experiments. In the first experiment, oysters were reared in controlled conditions of light, temperature and food availability. In the second experiment, oysters were injected 3 timesat weeklyintervals with $17 \beta$-estradiol and rearedinnatural conditions into the lagoon.

\subsection{Effect of food availability and temperature}

\subsubsection{Effect on gender determination}

The main objective of our environmental experiment was to test the hypothesis of environmental sex determinism (ESD) in P. margaritiferaadults.

Numerous vertebrates exhibit this sex determinism mode, mainly consisting in "temperaturedependent sex determination" (TSD)(Pieau et al., '99). For instance, among reptiles, gonadic differentiation is known to bebiased towards femaleat high temperature in most turtle species (Shoemaker and Crews, 2009), but biased towards male in some lizards (Hulin et al., 2009). In marine bivalves, only a few studies have shown the effect of environmental factors on sex ratioas a manner of induction of a male-biased sex ratio(Fabioux et al., 2005; Stenyakina et al., 2010; Santerre et al., 2013). Our results show a significant sex ratio change, determined histologically, for oysters conditioned at high temperature and low trophic level.Indeed in these environmental conditions, $50 \%$ of the initial females changed sex after 60 days, 
probably due to an energetic deficit. However, when looking at the molecular level using the 3-gene-pair expression ratio model, the proportion of regressed males identified as being on the male sexual pathway was significantly lower than expected in the treatment combining higher temperature conditions $\left(28^{\circ} \mathrm{C}\right)$ with high trophic level $\left(40,000\right.$ cells $\left.\mathrm{mL}^{-1}\right)$. It is therefore highly likely that we could induce a sex-reversal from male to femaleusing such conditions.Most previous studies that revealed a change in sex ratio in adult bivalves were conducted with a long conditioning time, generally over 1 year, as in the Pacific oyster $C$. gigas (more males at approximately $8{ }^{\circ} \mathrm{C}$ ) (Fabioux et al., 2005) or as in the tropical Cortez oyster C. corteziensis (more females at $9{ }^{\circ} \mathrm{C}$ ) (Rodríguez-Jaramillo et al., 2008). Our experiment lasted only two months, which corresponds to two reproductive cycles in $P$. margaritifera,but this duration could be insufficient to observe a significant effect of an environmental factor, especially temperature, on sex ratio.

The energetic deficit, hypothesized above, as source of sex inversion of $50 \%$ of the females, could be explainedbythe temperature fixed at $28{ }^{\circ} \mathrm{C}$ that would have increased the oxygen consumption and the metabolic rates, increasing the need for energy, as already demonstrated from 24 to $27{ }^{\circ} \mathrm{C}$ (Chávez-Villalba et al., 2013). Furthermore, in some molluscs, the production of female gametes is supposed to be more energetically costly than the production of male gametes, estimated at $50 \%$ more energy (Russell-Hunter, '79). To achievesex inversion, pearl oysters should initiate gametogenesis to renew a reproductive cycle.Bayne ('76)indicated that gametogenesis only begins when energetic reserves are sufficient. Poorly fed pearl oysters probably do not have enough energy from the diet and reserves at $28{ }^{\circ} \mathrm{C}$ to initiate gametogenesis and therefore change sex. At $28{ }^{\circ} \mathrm{C}$ and a high trophic level considered as a sufficient input of energy, we found only one female in the course of sexual inversion,suggesting that there areother forcing factors. A recent studyon $P$. margaritifera, has shown that at equal ingestion, females assimilate organic matter of ingested food better than males, and thus require a higher oxygen consumption (ChávezVillalba et al., 2013). This suggests that when females are subjected to a stress, an increase of their oxygen consumption could exacerbate the energetic deficit. Rearing techniques may be partially responsible and considered as stressful. We could hypothesize that the weekly cleaninggenerateda detrimental chronic stress for maintaining the female sex or/and the manifestation of new females. Some previous work has shown that the proportion of females has decreased for cultured pearl oysters compared with the natural stocks (Thielley, '93). In addition, Lacoste et al.(2014) observed a negative effect of monthly cleaning on female sex on farmed pearl oysters reared in a lagoon. It therefore appeared important to find nonstressful cleaning methods in order to consider only the effect of the environmental factors and promote females in aquaculture rearing.Energetic cost of sex inversion would be also of great interest for further studies to understand and to model sex determinism in $P$. margaritifera.

\subsubsection{Effect on gametogenesis}

Food availability is known to be an important factor for bivalve development, affecting broodstock energy reserves, fecundity, quality and quantity of eggs, and larval development(Berntsson et al., '97; Utting and Millican, '97; Hendriks et al., 2003; Delgado and Pérez-Camacho, 2005). In $P$. margaritifera, the present study clearly demonstrates, in experimental conditions, that the trophic level is a key parameter in the control of gametogenesis. Low trophic level seemed detrimental to the production of gametes, resulting in a high proportion of oysters in regression and therefore the cessation of gonialcellproduction. Conversely, a high concentration of microalgae promotedgonialcell proliferation and gamete maturation. These results confirm those of a study carried out byLe Moullac et al.(2013)showing that gonadic maturation and gonial proliferation of the pearl oyster is controlled by microalgal concentration. In this previous study, only $11 \%$ of individuals showedcomplete gametogenesis at the end of the first month of conditioning, 
whereas in our study,under the effect of a higher trophic level $(x 2.5)$, the proportion of oysterswith complete gametogenesisreached $60 \%$. The role of temperature in gametogenesis has also been demonstrated in many species of bivalves. Indeed, it was shown thatelevated temperatures in temperate zone (i.e. $\sim 19-20{ }^{\circ} \mathrm{C}$ ) promoted reproductive effort and maturation of germ cells (Mart nez and P rez, 2003; Fabioux et al., 2005). More precisely, it has been shown that the temperature regulates the speed and thus the duration of gametogenesis (Enríquez-Díaz et al., 2009).From a bioenergetic point of view,conditions were met in the present study to provide the maximum energy to oysters, i.e., a temperature of $28{ }^{\circ} \mathrm{C}$ (Yukihira et al., 2000) and a trophic level close to saturation (Le Moullac et al., 2013). Under these conditions, pearl oysters realized complete gametogenesis, going to spawning for some male and female individuals (data not shown). This study therefore offers an avenue forconditioning pearl oysters for reproductive maturation,but further research will be required to test for an effect of food quantity and quality on gamete quality and onthe subsequent implicationsfor offspring.

\subsection{Effect of $17 \beta$-estradiol}

The role of estrogens in the hormonal regulation of bivalve reproduction was suggested to be similar to that which they fulfill in vertebrate endocrine systems. Many studies in vertebrates, especiallyteleosts,showed that $17 \beta$-estradiol has a significant effect on reproduction, stimulating ovarian development and vitellogenin synthesis (de Vlaming et al., '80; Chang et al., '95; Kang et al., 2002). In this context, we made the first test of the potentialfeminizing effect of $17 \beta$-estradiol by directly injecting it into male gonadsof $P$. margaritifera. While no sex reversal from male to female was established during this experiment, a significantly lower proportion of male and a significantly higher proportion of undetermined oysters were found in the 17ß-estradiol-injected group after 28 days (i.e. 14 daysafter the third injection). Furthermore, regarding gametogenesis, we also foundsignificantly lower proportions of intermediate and mature gonads. These results strongly suggested that $17 \beta$-estradiolhas a negative effect on male gonad development in $P$. margaritifera, as in fishes. For example,Chang et al.('95)observed that $E_{2}$ treatment completely suppressed testicular development and spermiation in 2-years-old black porgyAcanthopagrusschlegeli. However, in $P$. margaritifera, it seemed that this negative effect disappears 6 weeks after the last injection,giving way to a positive effect on spermatogenesis. Indeed, although at the end of the experiment, a significantly higher proportion of mature gonadswas reported in $17 \beta-$ estradiol-injected oysters than in the control group, we observedan increase of sperm motility under the microscope for mature oysters of the $17 \beta$-estradiol-injected group compared with the control group at this time (data not shown). These results may seem to be contradictory to previous reports indicating the feminizing effect of estradiol in bivalves (Mori et al., '69; Varaksina and Varaksin, '91), but these effects are in accordance with other reports showing that estradiol can stimulate male reproductive activities. Indeed, it has been reported in other marine bivalves that estradiol stimulates spermatogenesis(Varaksina et al., '92; Wang and Croll, 2004), potentiates sperm release and spawning (Wang and Croll, 2003, 2006).If we supposed that $17 \beta$-estradiol quantity decreased in the gonad over the experiment, we can suggest that a residual quantity of $17 \beta$-estradiol (at the end of the experiment) could have a positive effect on spermatogenesis, whereas a high dose leads to the regression of the male differentiation. Therefore, our results show an effect of $17 \beta$-estradiol in reproduction of $P$. margaritifera, but further studies are needed to elucidate its function and mechanism of action.

\subsection{Probable dominance of genetic sex determinism in adult $\boldsymbol{P}$. margaritifera.}

The application of the model of the sexual pathway of $P$. margaritiferato real-time PCR results revealed that nine regressed male pearl oysters, overall the experiments, were molecularly on the female sexual pathway (i.e. across all conditions whether in the environmental and hormonal experiments). These nine animals represent $10 \%$ of the total 
analyzed pearl oysters. This ratio is not different to the female ratiofound in population of this average height (Chávez-Villalba et al., 2011), suggesting that whatever an environmental or hormonal treatment applied here, apreviously established genetic control seems to be dominant. In the Pacific oyster $C$. gigas, two genetic models have been proposed for sex determination (Guo et al., '98; Hedrick and Hedgecock, 2010). Whatever the model, the authors assumed that sex in $C$. gigaswould be controlled by a single major gene. Herein, we showed that among the nine marker genes only pmarg-foxl2 and pmarg-fem1-like appeared significantly differently expressed between pearl oysters in male and female sexual pathways, indicating that these two genes are involved at the top of the molecular cascades of sex determination in P. margaritifera. More recently, Santerre et al.(2013) suggested that C. gigasexhibits a mixed sex determination (GSD + TSD), ascan be observed for many fishesand amphibians (Valenzuela et al., 2003). In P. margaritifera, we did not exclude a mixed sex determination mode, GSD with ESD, but it appeared that adult sex determinism in this species is governed by more complex mechanisms. Indeed, this study covered only the effect of the exogenous factors temperature and food availability and the endogenous factor estradiol in adult pearl oysters. More studies will be required to better understand sex determination in this species, such as spat sex determination asrecently studied in $C$. gigas(Santerre et al., 2013), an alternative hermaphrodite mollusc, or with regard topopulation density as in Crepedulafornicata, a sequential hermaphrodite mollusc(Proestou, 2005).

Furthermore, this study also confirmed the utility and the capacity of the previously determined model based on the expression of three gene pairs to identifyoystersatthe onset of the female pathway.

\section{Conclusion}

In the present study, we found evidence for the environmental and,for the first time,hormonal control of the reproduction of $P$. margaritifera. Although no sex-reversal from male to female was observed, we suggest that environmental factors, and especially temperature combining with a predominant genetic controlmechanism, are involved in the gender determination of adult pearl oysters. Furthermore, high temperature and high trophic level appeared the best combination for broodstock conditioning in futurebreeding programs aimed at the sustainable development of pearl farming in French Polynesia. However, the sex determinism of $P$. margaritifera remains to be explored, with the two candidate genes pmarg-fox 2 and pmargfem1-like as the best starting points. Herein we covered adult sex determinism and it would be of great interest to study sex determinism in spat during first gonadic differentiation, likeSanterre et al.(2013) in the Pacific oyster C. gigas.

\section{Acknowledgments}

The authors are indebted to M. Sham Koua, M. Maihota, N. L. Tetaura,C. Soyez, H. Aurentz and A. Cizeron for their helpful assistance. We thankH. McCombie for her help in editing the English language.

\section{Funding information:}

This study was conducted as part of the ANR "POLYPERL" project (ANR-11-AGRO-006) and the Contract Project "BiodiPerl".V. Teaniniuraitemoanaisfinanciallysupported by Ifremer and holds a grantfrom la Délégation à la Recherche de Polynésie française. 


\section{Literature cited}

Bayne BL. 1976. Aspects of reproduction in bivalve molluscs. Estuar Process 1:432-448.

Bayne BL, Newell RC. 1983. Physiological Energetics of Marine Molluscs. In: Saleuddin ASM, Wilbur KM, editors. The Mollusca, Vol 4. London: Academic Press. p 407-515.

Berntsson KM, Jonsson PR, Wängberg SA, Carlsson AS. 1997. Effects of broodstock diets on fatty acid composition, survival and growth rates in larvae of the European flat oyster, Ostrea edulis. Aquaculture 154:139-153.

Chang CF, Lau EL, Lin BY. 1995. Estradiol-17 $\beta$ suppresses testicular development and stimulates sex reversal in protandrous black porgy, Acanthopagrus schlegeli. Fish Physiol Biochem 14:481-488.

Chávez-Villalba J, Soyez C, Huvet A, Gueguen Y, Lo C, Moullac G Le. 2011. Determination of gender in the pearl oyster Pinctada margaritifera. J Shellfish Res 30:231-240.

Chávez-Villalba J, Soyez C, Aurentz H, Le Moullac G. 2013. Physiological responses of female and male black-lip pearl oysters (Pinctada margaritifera) to different temperatures and concentrations of food. Aquat Living Resour 26:263-271.

Delgado M, Pérez-Camacho A. 2005. Histological study of the gonadal development of Ruditapes decussatus (L.) (Mollusca: Bivalvia) and its relationship with available food. Sci Mar 69:87-97.

De Vlaming VL, Wiley HS, Delahunty G, Wallace RA. 1980. Goldfish (Carassius auratus) vitellogenin: induction, properties and relationship to yolk proteins. Comp Biochem Physiol Part B 67:613-623.

Enríquez-Díaz M, Pouvreau S, Chávez-Villalba J, Le Pennec M. 2009. Gametogenesis, reproductive investment, and spawning behavior of the Pacific giant oyster Crassostrea gigas: evidence of an environment-dependent strategy. Aquac Int 17:491-506.

Fabioux C, Huvet A, Le Souchu P, Le Pennec M, Pouvreau S. 2005. Temperature and photoperiod drive Crassostrea gigas reproductive internal clock. Aquaculture 250:458470.

Fournier J, Levesque E, Pouvreau S, Le Pennec M, Le Moullac G. 2012. Influence of plankton concentration on gametogenesis and spawning of the black lip pearl oyster Pinctada margaritifera in Ahe atoll lagoon (Tuamotu Archipelago, French polynesia). Mar Pollut Bull 65:463-470.

Gauthier-Clerc S, Pellerin J, Amiard JC. 2006. Estradiol-17beta and testosterone concentrations in male and female Mya arenaria (Mollusca bivalvia) during the reproductive cycle. Gen Comp Endocrinol 145:133-139.

Gervis MH, Sims NA. 1992. The Biology and Culture of Pearl Oysters (Bivalvia: Pteriidae). ICLARM Stud Rev 21:1-49.

Gueguen Y, Montagnani C, Joubert C, Marie B, Belliard C, Tayalé A, Fievet J, Levy P, Piquemal D, Marin F, Le Moullac G, Ky C-L, Garen P, Lo C, Saulnier D. 2013. Characterization of molecular processes involved in the pearl formation in Pinctada margaritifera for the sustainable development of pearl farming industry in French Polynesia. In: Watabe S, Maeyama K, Nagasawa H, editors. Recent Advances in Pearl Research. Tokyo: TERRAPUB. p 183-193.

Guo X, Hedgecock D, Hershberger WK, Cooper K, Allen K. 1998. Genetic determinants of protandric sex in the Pacific oyster, Crassostrea gigas Thunberg. Evolution 52:394-402.

Hedrick PW, Hedgecock D. 2010. Sex determination: genetic models for oysters. J Hered 101:602-611.

Hendriks IE, Van Duren LA, Herman PM. 2003. Effect of dietary polyunsaturated fatty acids on reproductive output and larval growth of bivalves. J Exp Mar Bio Ecol 296:199-213.

Hulin V, Delmas V, Girondot M, Godfrey MH, Guillon J-M. 2009. Temperature-dependent sex determination and global change: are some species at greater risk? Oecologia 160:493-506. 
Kang IJ, Yokota H, Oshima Y, Tsuruda Y, Yamaguchi T, Maeda M, Imada N, Tadokoro H, Honjo T. 2002. Effect of $17 \mathrm{beta}$-estradiol on the reproduction of Japanese medaka (Oryzias latipes). Chemosphere 47:71-80.

Ketata I, Guermazi F, Rebai T, Hamza-Chaffai A. 2007. Variation of steroid concentrations during the reproductive cycle of the clam Ruditapes decussatus: a one year study in the gulf of Gabès area. Comp Biochem Physiol A Mol Integr Physiol 147:424-431.

Ky CL, Blay C, Sham-Koua M, Vanaa V, Lo C, Cabral P. 2013. Family effect on cultured pearl quality in black-lipped pearl oyster Pinctada margaritifera and insights for genetic improvement. Aquat Living Resour 26:133-145.

Ky CL, Blay C, Sham-Koua M, Lo C, Cabral P. 2014. Indirect improvement of pearl grade and shape in farmed Pinctada margaritifera by donor "oyster" selection for green pearls. Aquaculture 432:154-162.

Lacoste E, Le Moullac G, Levy P, Gueguen Y, Gaertner-Mazouni N. 2014. Biofouling development and its effect on growth and reproduction of the farmed pearl oyster Pinctada margaritifera. Aquaculture 434:18-26.

Le Moullac G, Tiapari J, Teissier H, Martinez E, Cochard JC. 2012. Growth and gonad development of the tropical black-lip pearl oyster, Pinctada margaritifera (L.), in the Gambier archipelago (French Polynesia). Aquac Int 20:305-315.

Le Moullac G, Soyez C, Sham-Koua M, Levy P, Moriceau J, Vonau V, Maihota M, Cochard JC. 2013. Feeding the pearl oyster Pinctada margaritifera during reproductive conditioning. Aquac Res 44:404-411.

Li Q, Osada M, Suzuki T, Mori K. 1998. Changes in vitellin during oogenesis and effect of estradiol- $17 \beta$ on vitellogenesis in the Pacific oyster Crassostrea gigas. Invertebr Reprod Dev 33:87-93.

Livak KJ, Schmittgen TD. 2001. Analysis of relative gene expression data using real-time quantitative PCR and the 2(-Delta Delta C(T)) Method. Methods 25:402-8.

Mart nez G, P rez H. 2003. Effect of different temperature regimes on reproductive conditioning in the scallop Argopecten purpuratus. Aquaculture 228:153-167.

Matsumoto T, Osada M, Osawa Y, Mori K. 1997. Gonadal estrogen profile and immunohistochemical localization of steroidogenic enzymes in the oyster and scallop during sexual maturation. Comp Biochem Physiol Part B Biochem Mol Biol 118:811817.

Mori K, Muramatsu T, Nakamura Y. 1969. Effect of steroid on oyster III: sex reversal from male to female in Crassostrea gigas by estradiol-17b. Bull Japanese Soc Sci Fish 35:1072-1076.

Moss SM. 1989. Effects of Exogenous androgens on growth, biochemical composition, and reproduction of the coot clam, Mulinia lateralis. Pacific Sci 43:200.

Osada M, Takamura T, Sato H, Mori K. 2003. Vitellogenin synthesis in the ovary of scallop, Patinopecten yessoensis: Control by estradiol-17 beta and the central nervous system. J Exp Zool A Comp Exp Biol 299:172-9.

Osada M, Tawarayama H, Mori K. 2004. Estrogen synthesis in relation to gonadal development of Japanese scallop, Patinopecten yessoensis: gonadal profile and immunolocalization of P450 aromatase and estrogen. Comp Biochem Physiol B Biochem Mol Biol 139:123-128.

Penman DJ, Piferrer F. 2008. Fish gonadogenesis. Part I: Genetic and environmental mechanisms of sex determination. Rev Fish Sci 16:16-34.

Pieau C, Dorizzi M, Richard-Mercier N. 1999. Temperature-dependent sex determination and gonadal differentiation in reptiles. Cell Mol life Sci 55:887-900.

Piferrer F, Guiguen Y. 2008. Fish gonadogenesis. Part II: Molecular biology and genomics of sex differentiation. Rev Fish Sci 16:35-55.

Pouvreau S, Gangnery A, Tiapari J, Lagarde F, Garnier M, Bodoy A. 2000. Gametogenic cycle and reproductive effort of the tropical blacklip pearl oyster, Pinctada margaritifera (Bivalvia: Pteriidae), cultivated in Takapoto atoll (French Polynesia). Aquat Living Resour 13:37-48. 
Pradeep PJ, Srijaya TC, Papini A, Chatterji AK. 2012. Effects of triploidy induction on growth and masculinization of red tilapia [Oreochromis mossambicus (Peters, 1852)×Oreochromis niloticus (Linnaeus, 1758)]. Aquaculture 6:181-187.

Proestou DA. 2005. Sex change in Crepidula fornicata: influence of environmental factors on reproductive success and the timing of sex change.

R Development Core Team R. 2011. R: A Language and Environment for Statistical Computing. R Found Stat Comput 1:409.

Rodríguez-Jaramillo C, Hurtado M a., Romero-Vivas E, Ramírez JL, Manzano M, Palacios E. 2008. Gonadal development and histochemistry of the Tropical oyster, Crassostrea corteziensis (Hertlein, 1951) during an annual reproductive cycle. J Shellfish Res 27:1129-1141.

Russell-Hunter WD. 1979. The evolution of filter-feeding bivalves. In: A life of invertebrates. New-York: MacMillan Publishing Company. p 656.

Santerre C, Sourdaine P, Marc N, Mingant C, Robert R, Martinez A-S. 2013. Oyster sex determination is influenced by temperature - first clues in spat during first gonadic differentiation and gametogenesis. Comp Biochem Physiol A Mol Integr Physiol 165:6169.

Sastry AN. 1979. Pelecypoda (excluding Ostreidae). In: Giese AC, Pearse JS, editors. Reproduction of marine molluscs. New York: Academic Press. p 113-292.

Scott AP. 2012. Do mollusks use vertebrate sex steroids as reproductive hormones? Part I: Critical appraisal of the evidence for the presence, biosynthesis and uptake of steroids. Steroids $77: 1450-1468$.

Scott AP. 2013. Do mollusks use vertebrate sex steroids as reproductive hormones? II. Critical review of the evidence that steroids have biological effects. Steroids 78:268281.

Shoemaker CM, Crews D. 2009. Analyzing the coordinated gene network underlying temperature-dependent sex determination in reptiles. Semin Cell Dev Biol 20:293-303.

Stenyakina A, Walters LJ, Hoffman EA, Calestani C. 2010. Sex expression and environmental-stress in a mollusk, Pinctada margaritifera. Mol Reprod Dev 77:222-230.

Suquet M, De Kermoysan G, Araya RG, Queau I, Lebrun L, Le Souchu P, Mingant C. 2009. Anesthesia in Pacific oyster, Crassostrea gigas. Aquat Living Resour 22:29-34.

Tayalé A, Gueguen Y, Treguier C, Le Grand J, Cochennec-Laureau N, Montagnani C, Ky CL. 2012. Evidence of donor effect on cultured pearl quality from a duplicated grafting experiment on Pinctada margaritifera using wild donors. Aquat Living Resour 25:269280.

Teaniniuraitemoana V, Huvet A, Levy P, Klopp C, Lhuillier E, Gaertner-Mazouni N, Gueguen Y, Le Moullac G. 2014. Gonad transcriptome analysis of pearl oyster Pinctada margaritifera: identification of potential sex differentiation and sex determining genes. BMC Genomics 15:491.

Teaniniuraitemoana V, Huvet A, Levy P, Gaertner-Mazouni N, Gueguen Y, Le Moullac G. 2015. Molecular signatures discriminating the male and the female sexual pathways in the pearl oyster Pinctada margaritifera. PLoS One 10:e0122819.

Thielley M. 1993. Etude cytologique de la gamétogenèse, de la sex-ratio et du cycle de reproduction chez l'huître perlière Pinctada margaritifera $(L)$ var. cumingii (Jameson), (mollusque, bivalves). Comparaison avec le cycle de Pinctada maculata (Gould).

Tranter D. 1958. Reproduction in australian pearl oysters (Lamellibranchia). IV. Pinctada margaritifera (Linnaeus). Mar Freshw Res 9:509-525.

Utting SD, Millican PF. 1997. Techniques for the hatchery conditioning of bivalve broodstocks and the subsequent effect on egg quality and larval viability. Aquaculture 155:45-54.

Valenzuela N, Adams DC, Janzen FJ, The S, Naturalist A, April N. 2003. Pattern Does Not Equal Process : Exactly When Is Sex Environmentally Determined? Am Nat 161:676683.

Varaksina GS, Varaksin AA. 1991. Effects of estradiol, progesterone, and testosterone on oogenesis of yezo scallop. Biol Morya 3:61-68. 
Varaksina GS, Varaksin AA, Maslennikova LA. 1992. The role of gonadal steroid hormones in the spermatogenesis of the scallop Mizuhopecten yessoensis. Biol Morya 3:77-83.

Wang C, Croll RP. 2003. Effects of sex steroids on in vitro gamete release in the sea scallop, Placopecten magellanicus. Invertebr Reprod Dev 44:89-100.

Wang C, Croll RP. 2004. Effects of sex steroids on gonadal development and gender determination in the sea scallop, Placopecten magellanicus. Aquaculture 238:483-498.

Wang C, Croll RP. 2006. Effects of sex steroids on spawning in the sea scallop, Placopecten magellanicus. Aquaculture 256:423-432.

Wedekind C, Stelkens RB. 2010. Tackling the diversity of sex determination. Biol Lett 6:7-9.

Yukihira H, Lucas JS, Klumpp DW. 2000. Comparative effects of temperature on suspension feeding and energy budgets of the pearl oysters Pinctada margaritifera and P. maxima. Mar Ecol Prog Ser 195:179-188.

Zanini JM, Salvat B. 2000. Assessment of deep water stocks of pearl oysters at Takapoto Atoll (Tuamotu Archipelago, French Polynesia). Coral Reefs 19:83-87. 
Table 1. Primers used for real time PCR.

\begin{tabular}{lllll}
\hline Gene names & $\begin{array}{l}\text { Genbank } \\
\text { Accession } \\
\text { numbers }\end{array}$ & Primer names & $\begin{array}{l}\text { Forward } \\
\text { vs } \\
\text { Reverse }\end{array}$ & Sequences (5'-3') \\
\hline pmarg-foxl2 & KJ907378 & FOXL2_1S & F & TCCGGATCACAGTGTCTCAG \\
pmarg-c43476 & KM874285 & C43476_VF_1S & F & ACCCTTACCAATCACCCTGC \\
pmarg-c45042 & KM874286 & C45042_VF_2S & F & GAGTGGAAGCAAGACAGACCA \\
pmarg-c19309 & KM874287 & C19309_NFMRF_2S & F & GATGCACTAGACACGCCTGA \\
& & C19309_NFMRF_2AS & R & ACATGGATCTCTGTAACGCGT \\
pmarg-c54338 & KM874288 & C54338_NFMRF_1S & F & CGTCTTCTCTAATTCACG \\
& & C54338_NFMRF_1AS & R & CAGTACACACCATGATTGA \\
pmarg-vit6 & KM874283 & Vit-6_2S & F & GTCCGCCCAGTAAACAAAGA \\
& & Vit-6_2AS & R & CAATGTTGGTCCAGCTTCCT \\
pmarg-zglp1 & KM874284 & ZGLP1_4S & F & AGGCTTCTTTGTCAGACCACA \\
& & ZGLP1_4AS & R & GTGCTGAGAGATGTGATCCCA \\
pmarg-dmrt & KJ907374 & Dmrt_2S & F & AACCTCTGGGTGACAACTGG \\
& & Dmrt_2AS & R & ATCCAGGACCACAGGTTCAG \\
pmarg-fem1-like & KJ907377 & FEM-1_4S & F & ACTCCACAACCAGCTTTCACA \\
& & FEM-1_4AS & R & GTGCCGATGTGACACTGAGA \\
ef1a & - & EF1a5_S & F & CCACGAGTCCTTACCAGAGG \\
gapdh1 & - & EF1a5_AS & R & TGGATCACTTTTGCTGTCTCC \\
& & GAPDH1_S & F & AGGCTTGATGACCACTGTCC \\
& & GAPDH1_AS & R & AGCCATTCCCGTCAACTTC \\
\hline
\end{tabular}


Table 2.Number of male, female, as well as undetermined and inversion stages of Pinctadamargaritifera in each condition of the two experiments.

\begin{tabular}{|c|c|c|c|c|c|}
\hline Time & Condition & Male & Female & Undetermined & Inversion \\
\hline \multicolumn{6}{|c|}{ Experiment 1 (Exp1) } \\
\hline do & - & 32 & 8 & $0<$ & $0<$ \\
\hline \multirow[t]{4}{*}{$\mathrm{d} 30$} & $24^{\circ} \mathrm{C}-10,000$ cells $\mathrm{mL}^{-1}$ & 31 & 7 & 1 & $0^{<}$ \\
\hline & $24^{\circ} \mathrm{C}-40,000$ cells $\mathrm{mL}^{-1}$ & 32 & 8 & $0<$ & $0<$ \\
\hline & $28^{\circ} \mathrm{C}-10,000$ cells $\mathrm{mL}^{-1}$ & 29 & 6 & 3 & $0<$ \\
\hline & $28^{\circ} \mathrm{C}-40,000$ cells $\mathrm{mL}^{-1}$ & 30 & 8 & $0<$ & $0<$ \\
\hline \multirow[t]{4}{*}{$d 60$} & $24^{\circ} \mathrm{C}-10,000$ cells $\mathrm{mL}^{-1}$ & 30 & 5 & 4 & $0<$ \\
\hline & $24^{\circ} \mathrm{C}-40,000$ cellsmL - & 28 & 6 & 2 & 2 \\
\hline & $28^{\circ} \mathrm{C}-10,000$ cells $\mathrm{mL}^{-1}$ & 32 & $2^{<}$ & 2 & $4^{>}$ \\
\hline & $28^{\circ} \mathrm{C}-40,000$ cells $\mathrm{mL}^{-1}$ & 30 & 7 & $0^{<}$ & 1 \\
\hline \multicolumn{6}{|c|}{ Experiment 2 (Exp2) } \\
\hline d0 & - & 19 & 0 & 1 & 0 \\
\hline \multirow[t]{2}{*}{$\mathrm{d} 28$} & $17 \beta$-Estradiol & $36^{<}$ & 0 & $8^{>}$ & 0 \\
\hline & Control & 43 & 0 & 5 & 0 \\
\hline \multirow[t]{2}{*}{ d56 } & $17 \beta$-Estradiol & 39 & 0 & $0<$ & 0 \\
\hline & Control & $47^{>}$ & 0 & $0^{<}$ & 0 \\
\hline
\end{tabular}

Table 3.Number of pearl oysters Pinctadamargaritifera determined in male or female sexual pathway using the predictive 3-gene-pair expression ratio model of the sexual pathway proposed in Teaniniuraitemoana et al. (2015).

\begin{tabular}{lccc}
\hline Condition & Femalepathway & Male pathway & Total \\
\hline Experiment 1 (Exp1) & 3 & & \\
$24^{\circ} \mathrm{C}-10,000 \mathrm{cells} \mathrm{mL}^{-1}$ & $0^{<}$ & 24 & 27 \\
$24^{\circ} \mathrm{C}-40,000 \mathrm{cells} \mathrm{mL}^{-1}$ & 1 & 13 & 13 \\
$28^{\circ} \mathrm{C}-10,000 \mathrm{cells} \mathrm{mL}^{-1}$ & 1 & 12 & 13 \\
$28^{\circ} \mathrm{C}-40,000 \mathrm{cells} \mathrm{mL}^{-1}$ & 5 & 1 & 2 \\
Subtotal & & 50 & 55 \\
Experiment 2 (Exp2) & 2 & & \\
17ß-Estradiol & 2 & 20 & 22 \\
Control & 4 & 11 & 13 \\
Subtotal & $\mathbf{9}$ & 31 & 35 \\
Total & 81 & 90 \\
\hline T
\end{tabular}

indicates a significant higher number between conditions $(\mathrm{p}<0.05$, Fisher exact test). 


\section{Figures}

Fig. 1 Frequency of maturity stages observed by histology in the environmental experiment (Exp1). Number of animals ( $n$ ) sampled at each sampling time and each treatmentare indicated below each histogram. The corresponding sampling times are indicated above histograms with horizontal brackets.> indicates a significant higher number and $<$ a significant lower number between conditions than predicted $(p<0.05$, Fisher's exact test).24-10: $24{ }^{\circ} \mathrm{C}-10,000$ cells $\mathrm{mL}^{-1} ; 24-40: 24{ }^{\circ} \mathrm{C}-40,000$ cells $\mathrm{mL}^{-1} ; 28-10: 28{ }^{\circ} \mathrm{C}-10,000$ cells $\mathrm{mL}^{-1} ; 28-40: 28{ }^{\circ} \mathrm{C}-40,000$ cells $\mathrm{mL}^{-1}$; $\mathrm{d} 0$ : the beginning of the experiment; $\mathrm{d} 30$ : after 30 days of conditioning; and d60: after 60 days of conditioning, the end of the experiment.

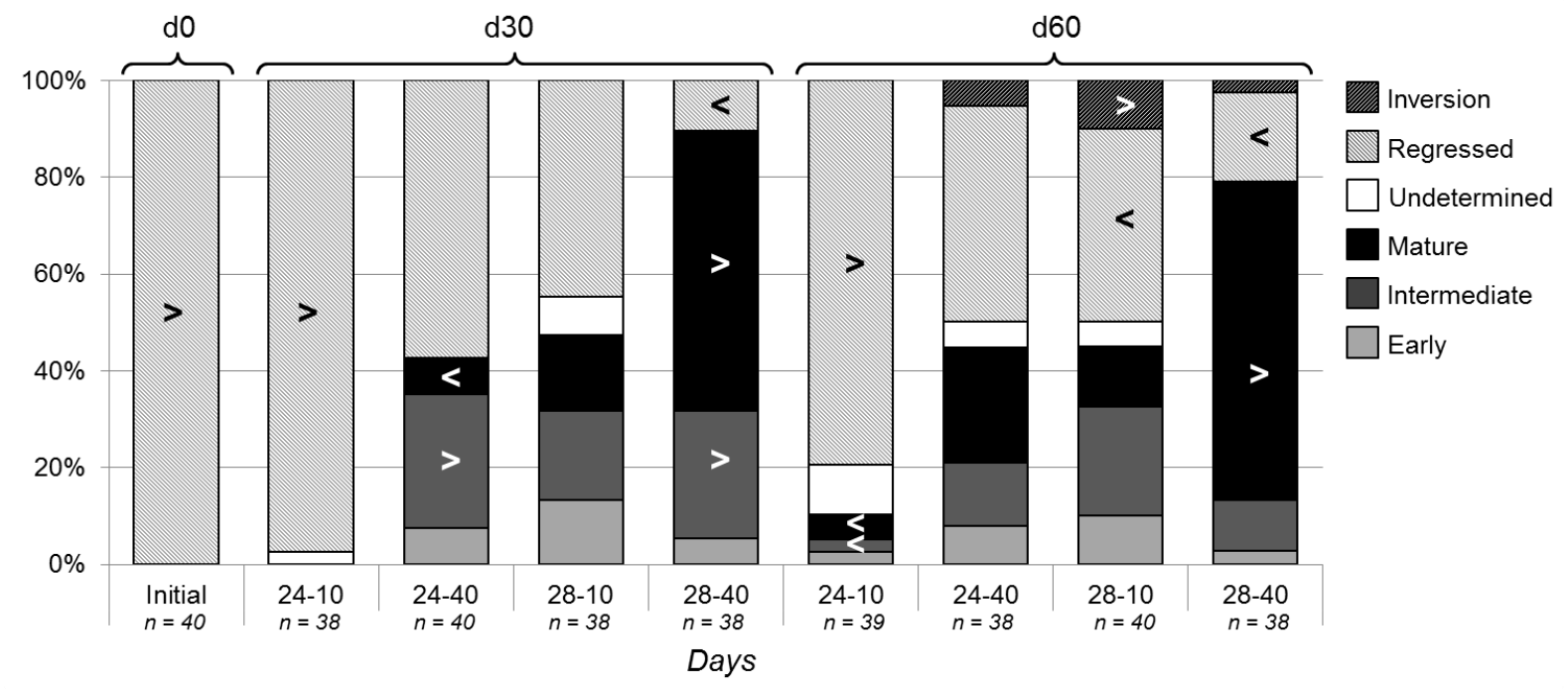


Fig. 2 Frequency of maturity stages observed by histology in the hormonal experiment (Exp2). Number of animals ( $n$ ) sampled at each sampling time and each treatmentare indicated below each histogram. The corresponding sampling times are indicated above histograms with horizontal brackets. > indicates a significant higher number and < a significant lower number between conditions than expected $(p<0.05$, Fisher's exact test). $17 \beta$-Estradiol: oysters injected with a $0.5 \mu \mathrm{g} \mathrm{L}^{-1} 17 \beta$-estradiol solution; Control: oysters injected with a 1:100 mixture of ethanol and sterilized seawater (Control solution); d0: the beginning of the experiment; d28: after 28 days of experiment, two weeks after the final injection; and d56: after56 days of experiment, 6 weeks after the final injection, the end of the experiment.

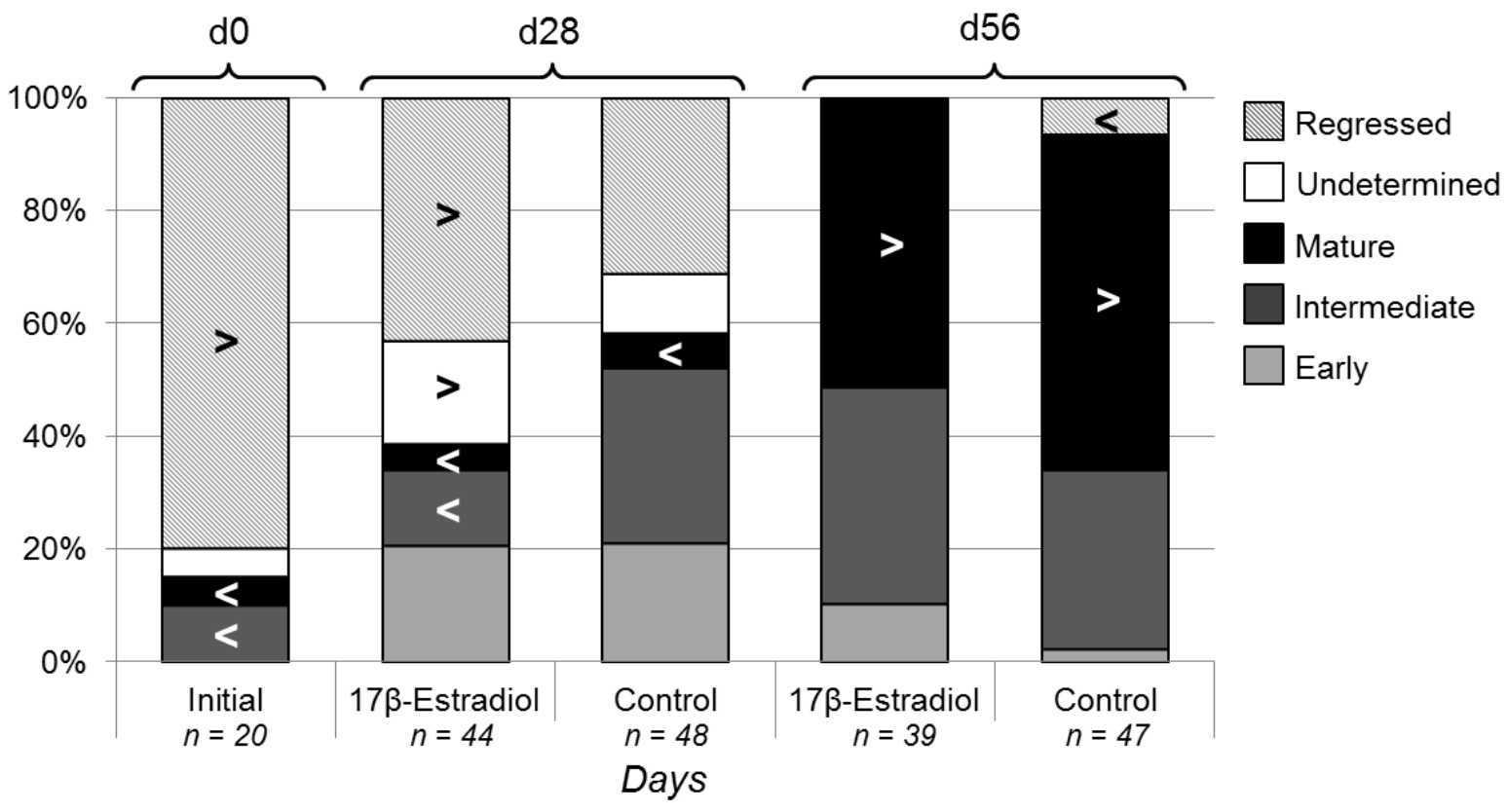


Fig. 3 Relative expression profiles (real time PCR) of pmarg-foxl2 (A), pmarg-c43476 (B), pmarg-c45042 (C), pmarg-c19309 (D), pmarg-c54338 (E), vit-6 (F), zglp1 (G), pmargdmrt $(\mathrm{H})$, and pmarg-fem1-like (I) in pearl oysters on male and female sexual pathways. * indicates statistically significant differences determined by a Wilcoxon test $(p<0.05)$.

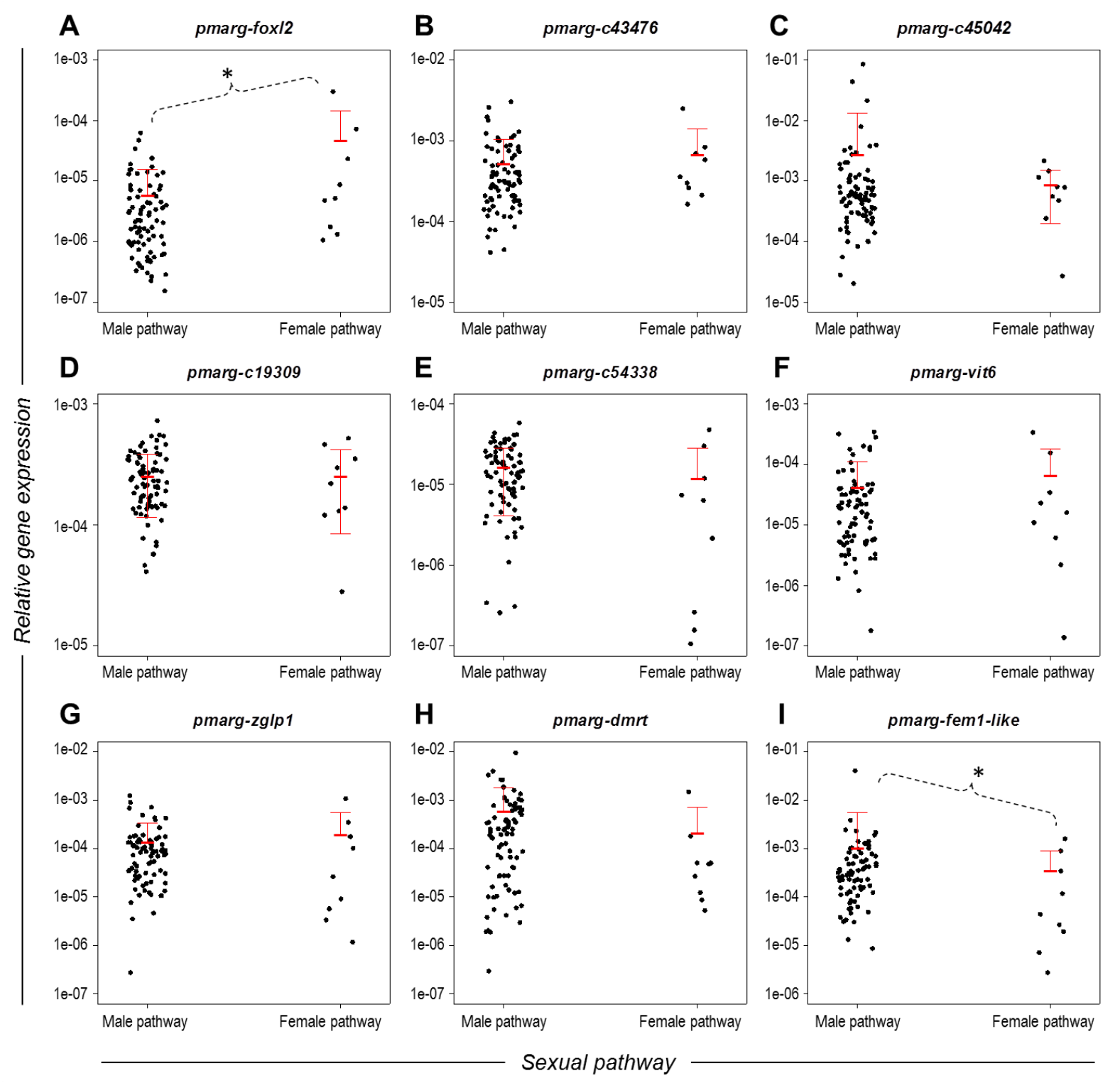

